\title{
Bioreduction of (Z)-3-halo-4-phenyl-3-buten-2-one mediated by Pichia stipitis in ionic liquids
}

\author{
Dávila S. Zampieri, Bruno R. S. de Paula, Luiz A. Zampieri, Tarcila Cazetta, J. \\ Augusto R. Rodrigues e Paulo J. S. Moran*
}

State University of Campinas, Chemistry Institute, PO BOX 6154, CEP 13083-970, Campinas/SP, Brazil.

*moran@iqm.unicamp.br.

Keywords: biphasic system, halohydrin, Pichia stipitis, ionic liquid

\section{INTRODUCTION}

Ionic liquids are substances that are completely composed of ions and are liquid at or close to room temperature. ${ }^{1}$ Biocatalysis in ionic liquids media was first reported in 2000. In our studies towards the synthesis of chiral halohydrins using $\left[\mathrm{bmim}\left(\mathrm{BF}_{4}\right)\right]$ (water-miscible) and [bmim $\left.\left(\mathrm{PF}_{6}\right)\right]$ (water-immiscible), one of the approaches was the bioreduction of the correspondent $\alpha$-haloenones mediated by Pichia stipitis, so as to generate two stereogenic centers in the same reaction.

\section{RESULTS AND DISCUSSION}

The bioreduction of $\mathbf{1 a}$ or $\mathbf{1 b}(100 \mathrm{mg})$ in $100 \mathrm{~mL}$ of a slurry of Pichia stipitis, was performed in a shaker at 200 or $400 \mathrm{rpm}$ and $30^{\circ} \mathrm{C}$ for 24 hours (Figure 1). The results of experiments with addition of $1 \mathrm{~mL}$ of ionic liquid [bmim( $\left.\left(\mathrm{BF}_{4}\right)\right]$ or $\left[\mathrm{bmim}\left(\mathrm{PF}_{6}\right)\right]$ are presented in Table 1.

Table 1. Reduction of $\mathbf{a}$-haloenones $\mathbf{1 a - b}$ mediated by Pichia stipitis

\begin{tabular}{|c|c|c|c|c|}
\hline \multirow[t]{2}{*}{ Substrate } & \multirow[t]{2}{*}{$\begin{array}{l}\text { Ionic liquid } \\
(\mathrm{mL})\end{array}$} & \multicolumn{3}{|c|}{$\begin{array}{c}\text { Conversion after } 24 \mathrm{~h} \\
(\%)^{\mathrm{c}}\end{array}$} \\
\hline & & 2 & 3 & 4 \\
\hline \multirow[t]{3}{*}{$1 a$} & without $^{\mathrm{a}}$ & 42 & 33 & --- \\
\hline & {$\left[\mathrm{bmim}\left(\mathrm{BF}_{4}\right)\right]^{\mathrm{a}}$} & 46 & 21 & --- \\
\hline & {$\left[\mathrm{bmim}\left(\mathrm{PF}_{6}\right)\right]$} & $28^{a} / 22^{b}$ & --- & $8^{a} / 32^{b}$ \\
\hline \multirow[t]{3}{*}{$1 b$} & without $^{\mathrm{a}}$ & 59 & 36 & --- \\
\hline & {$\left[\mathrm{bmim}\left(\mathrm{BF}_{4}\right)\right]^{\mathrm{a}}$} & 68 & 29 & --- \\
\hline & {$\left[\mathrm{bmim}\left(\mathrm{PF}_{6}\right)\right]$} & $4^{a} / 9^{b}$ & --- & $46^{\mathrm{a}} / 74^{\mathrm{b}}$ \\
\hline
\end{tabular}

Reaction conditions: ${ }^{a} 100 \mathrm{mg}$ of substrate in $100 \mathrm{~mL}$ of growth medium with $1 \mathrm{~mL}$ ionic liquid; ${ }^{\mathrm{b}} 100 \mathrm{mg}$ of substrate in $200 \mathrm{~mL}$ of growth medium with $1 \mathrm{~mL}$ ionic liquid; 'oncentrations determined by $\mathrm{GC} / \mathrm{MS}$ analysis.

The production of halohydrins $\mathbf{4 a}$ and $\mathbf{4 b}$ (in high ee 97 e $98 \%$ respectively), was only observed in reactions using the biphasic system ionic liquid/water, while the dehalogenated ketone $\mathbf{3}$ was produced when the reaction was performed with the water-miscible ionic liquid or even without addition of any ionic liquid. The haloketone $\mathbf{2}$ was detected as an intermediate of the reactions (Figure 1).

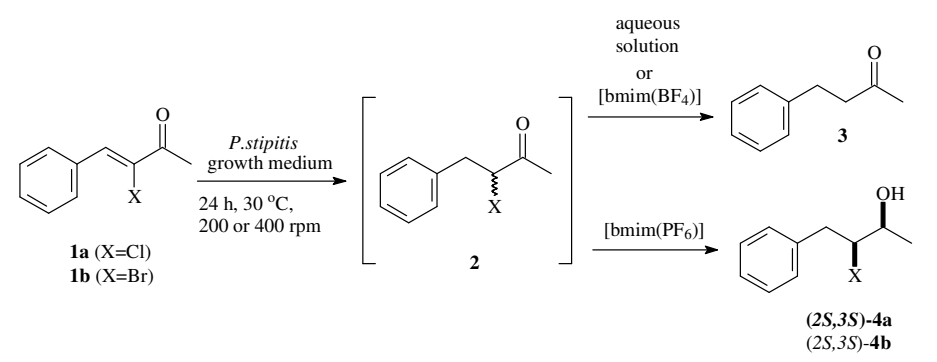

Figure 1.

In the biphasic system, the cells are dispersed in water phase while the organic compounds are mainly in the ionic liquid phase due to their partition constants. The concentrations of $\mathbf{1 a}$ and $\mathbf{1 b}$ in water drop from $1 \mathrm{mg} / \mathrm{mL}$ to 0.054 and $0.035 \mathrm{mg} / \mathrm{mL}$ respectively in biphasic system (Figure 2). It is reasonable to propose that the concentration of 2 in water in the biphasic system is also much lower than in the aqueous system with single phase, driving the reaction to formation of $\mathbf{4 a}$ and $\mathbf{4 b}$.

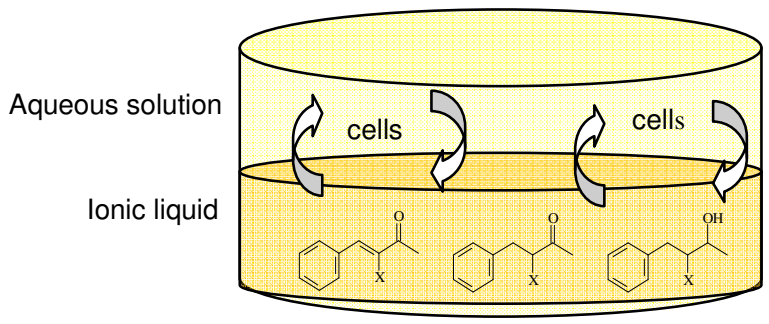

Figure 2.

\section{CONCLUSION}

The biphasic system may be equivalent to a process of in situ extractive biocatalysis, giving $\mathbf{4 a}$ and $\mathbf{4 b}$ in high ee.

\section{ACKNOWLEDGEMENTS}

CNPq and FAPESP.

\section{REFERENCES}

van Rantwijk, F. e Sheldon, R. A. Chem. Rev. 2007, 107, 2757-2785. 